\title{
PERANCANGAN PERBAIKAN SISTEM INFORMASI PADA PROSES PEMBUATAN PENAWARAN SUKU CADANG DIVISI SERVICE MENGGUNAKAN METODE ANALISI PIECES DAN PENDEKATAN TERSTRUKTUR (Studi Kasus : PT. JK)
}

\author{
Mutmainah $^{1^{*}}$, Deti Anggraeni Akbar ${ }^{1}$ \\ ${ }^{1}$ Jurusan Teknik Industri Fakultas Teknik Universitas Muhammadiyah Jakarta \\ Jl. Cempaka Putih Tengah 27 Jakarta 10510 \\ *Email : mutmainah.mattjik@yahoo.co.id
}

\begin{abstract}
ABSTRAK
Studi dilakukan pada PT JK perusahaan kontraktor pemasang elevator dan eskalator merk Goldstar / LG / SIGMA (Agen Tunggal Pemegang Merk) dan pelayanan berupa jasa pemeliharaan dan perawatan. Divisi Service mendapatkan keluhan pelanggan perihal lamanya proses pembuatan penawaran suku cadang. Setelah dianalisa penyebabnya, kendala yang dialami dikarenakan terdapat keterlambatan pada proses pengiriman Form Permintaan Penawaran ke kantor pusat oleh Tim Operasional dan proses pembuatan penawaran suku cadang oleh Tim Marketing. Keterlambatan disebabkan karena pengiriman Form Permintaan Penawaran masih manual dan informasi pada Form Permintaan Penawaran suku cadang yang kurang spesifik, sehingga waktu aktual pelaksanaannya melebihi waktu standar yang telah ditetapkan perusahaan. Penelitian dilakukan dengan perancangan perbaikan sistem informasi proses pembuatan penawaran suku cadang. Pengolahan data menggunakan Metode Analisis PIECES dan Pendekatan Terstruktur, dengan tujuan supaya keterlambatan pada proses pembuatan penawaran suku cadang tidak terjadi lagi. Dari hasil pengolahan data dengan Analisis PIECES dan melakukan Pendekatan Terstruktur, dilakukan perbaikan dengan mengirim Form Permintaan Penawaran Suku Cadang yang dibuat dalam bentuk Excel dikirim secara online via email dan dapat diakses melalui web server. Sehingga keterlambatan pada proses pembuatan penawaran suku cadang tidak terjadi lagi dan perusahaan dapat mengatasi keluhan pelanggan.
\end{abstract}

Kata kunci : Keluhan Pelanggan, Perbaikan Sistem Informasi, Service, Web Server.

\section{ABSTRACT}

PT. JK is a contractor company that installs elevators and escalators of the Goldstar / LG / SIGMA brand (Sole Agent Brand Holder) and maintenance services. The Service Division received customer complaints about the time of the process of quotation parts. After analyzing, the constraints experienced were due to a delay in the process of sending the Quotation Request Form to the head office by the Operations Team and the process of making quotation parts by the Marketing Team. Delay is caused by the sending of the Quotation Request Form that is still manual and the information on the Quotation Request Form for spare parts that are less specific, so that the actual execution time exceeds the standard. To overcome the problems, the authors conducted research relating to the design of information systems improvement processes for making quotation parts. Data processing using the PIECES Analysis Method and Structured Approach, in order to reduce the delays in the process of making quotation spare parts. From the results of data processing with PIECES Analysis and using a Structured Approach, improvements are made by sending the Quotation Request Form made in Excel form sent online via email and can be accessed through a web server. And by using the formula in the Excel Quotation Request Form to bring up the price of spare parts based on the part number. So, the delay in the process of making Quotation parts does not happen again and the company can resolve customer complaints.

Keywords: Customer Complaint, Information System, Service, Web Server. 


\section{PENDAHULUAN}

PT. JK telah dipercaya sebagai perusahaan pemasang elevator (lift) dan eskalator merk Goldstar (ATPM - Agen Tunggal Pemegang Merk) yang sekarang bereformasi menjadi merk LG / SIGMA. Selain pemasangan, pelayanan yang diberikan juga berupa jasa pemeliharaan dan perawatan lift dan eskalator.

Dalam pelaksanaannya, terdapat divisi Lift Escalator Marketing (LEM), divisi Lift Escalator Project (LEP) dan divisi Lift Escalator Service (LES). Jasa pemeliharaan unit lift dan eskalator yang rutin dijalankan, serta pengadaan dan penggantian suku cadang unit lift dan eskalator menghasilkan pendapatan terbesar untuk PT. JK. Divisi Service berinteraksi langsung dengan pelanggan dalam melaksanakan pekerjaan pemeliharaan unit lift dan eskalator, yang terdiri dari kegiatan penjadwalan kunjungan pemeliharaan, kunjungan pemeliharaan unit lift dan eskalator, merekomendasikan penggantian suku cadang dengan mengajukan penawaran, negosiasi dan menerima PO (Purchase Order), menyediakan suku cadang dan menjadwalkan pemasangannya, mengurus administrasi dan melakukan penagihan atas pekerjaan pemeliharaan unit lift dan eskalator atau pekerjaan penggantian suku cadang.

Dari data terakhir, perusahaan menerima keluhan pelanggan terkait pelayanan divisi Service. adalah sebagai berikut :

Tabel 1. Rekap Keluhan Pelanggan

\begin{tabular}{|l|c|}
\hline \multicolumn{1}{|c|}{ Keluhan } & Jumlah Proyek \\
\hline Penagihan Terlambat & 5 \\
\hline Kurangnya Ketersediaan Suku Cadang & 4 \\
\hline Jadwal Service Tidak Tepat Waktu & 3 \\
\hline $\begin{array}{l}\text { Lamanya Proses Pembuatan Penawaran } \\
\text { Suku Cadang }\end{array}$ & 22 \\
\hline Kemampuan Teknisi Service & 4 \\
\hline
\end{tabular}

Dari data Rekap Keluhan Pelanggan dapat diketahui bahwa keluhan pelanggan terbanyak yaitu lamanya proses pembuatan penawaran suku cadang. Setelah diamati, terdapat ketidaksesuaian proses dalam pembuatan penawaran suku cadang sehingga menimbulkan perbedaan waktu penyelesaiaan dan mengakibatkan adanya keluhan pelanggan.

Ketidaksesuaian proses yang terjadi yaitu pada proses pengiriman Form Permintaan Penawaran ke kantor pusat oleh Tim Operasional dengan standar waktu 10 hari kerja, namun aktualnya bisa mencapai 20 hari kerja atau lebih dikarenakan proses pengiriman yang masih manual. Kendala yang terjadi juga terdapat pada proses pengecekan ketersediaan stok suku cadang oleh Sparepart Officer yang masih melakukan pengecekan secara manual. Dan penulisan suku cadang yang kurang spesifik pada Form Permintaan Penawaran oleh Tim Operasional juga menyebabkan Sparepart Officer kesulitan dalam melakukan pengecekan ketersediaan stok suku cadang. Kemudian penulisan suku cadang yang kurang spesifik pada Form Permintaan Penawaran oleh Tim Operasional juga menjadi penyebab proses pembuatan penawaran suku cadang oleh Tim Marketing dengan standar waktu 2 hari kerja, namun aktualnya bisa mencapai 5 hari kerja karena Marketing Officer harus memastikan spesifikasi suku cadang terlebih dahulu agar tidak salah dalam memberikan harga. Kebutuhan waktu proses berlebih disebabkan karena saat Marketing Officer ingin memastikan spesifikasi suku cadang yang akan diberikan harga, namun Tim Operasional yang mengetahui pasti perihal spesifikasi suku cadang sedang berada di area lapangan / proyek dan jarang berada di kantor pusat.

Tabel 2. Waktu Proses Pembuatan Penawaran Suku Cadang

\begin{tabular}{|c|c|c|c|}
\hline \multirow{2}{*}{ Proses } & \multicolumn{2}{|c|}{ Waktu Proses (hk) } & \multirow{2}{*}{$\begin{array}{l}\text { Selisih Waktu } \\
\text { Proses (hk) }\end{array}$} \\
\hline & Standar & Aktual & \\
\hline Pemeliharaan unit lift dan eskalator & 1 & 1 & 0 \\
\hline $\begin{array}{l}\text { Pengiriman Form Permintaan Penawaran } \\
\text { ke kantor pusat oleh Tim Operasional }\end{array}$ & 10 & 20 & 10 \\
\hline Pengecekan ketersediaan stok suku cadang & 1 & 1 & 0 \\
\hline $\begin{array}{l}\text { Form Permintaan Penawaran diserahkan ke } \\
\text { Tim Marketing }\end{array}$ & 1 & 1 & 0 \\
\hline Pembuatan penawaran suku cadang & 2 & 5 & 3 \\
\hline $\begin{array}{l}\text { Pengajuan penawaran suku cadang oleh } \\
\text { Tim Marketing ke pelanggan }\end{array}$ & 1 & 1 & 0 \\
\hline $\begin{array}{c}\text { Total } \\
\end{array}$ & 16 & 29 & 13 \\
\hline
\end{tabular}

Ketidaksesuaian proses bersumber dari permasalahan dalam pencantuman dan pengiriman informasi perihal rekomendasi penggantian suku cadang dari Tim Operasional di lapangan kepada Tim Marketing di kantor pusat. Dengan pelaksanaan proses kerja yang masih manual, ketidaksesuaian proses tidak dapat dihindari dan akan terus terjadi. Perbaikan sistem dalam pencantuman dan pengiriman informasi secara online via email dan web 
dengan mempertimbangkan kendala yang terjadi saat pelaksanaan proses, diharapkan dapat mengatasi permasalahan yang terjadi di perusahaan. Dengan adanya perbaikan sistem informasi, divisi Service bisa mengatasi permasalahan yang menjadi penyebab keluhan pelanggan. Dalam perbaikan sistem informasi, diperlukan analisis terhadap kinerja, informasi , ekonomi, pengendalian, efisiensi dan pelayanan menggunakan metode Analisis PIECES untuk mengetahui perbandingan antara sistem yang lama dan sistem baru yang sudah diperbaiki. Menggunakan metode pendekatan terstruktur, yaitu perancangan perbaikan sistem dari atas ke bawah atau dari awal sampai ke akhir.

\section{TINJAUAN PUSTAKA}

\section{Lift dan Eskalator}

Menurut definisi kamus bahasa Indonesia Lift (elevator) adalah . alat transportasi pada bangunan yang bergerak secara vertikal yang membawa penumpang, peralatan, dan muatan dari satu tingkat ke tingkat yang lain. Lift umumnya digunakan di gedung-gedung bertingkat tinggi, biasanya lebih dari tiga atau empat lantai. Gedung-gedung yang lebih rendah biasanya hanya menggunakan tangga atau eskalator. Demikian jufa dengan Eskalator atau tangga berjalan adalah salah satu transportasi vertikal berupa konveyor untuk mengangkut orang, yang terdiri dari tangga terpisah yang dapat bergerak ke atas dan ke bawah mengikuti jalur yang berupa rail atau rantai yang digerakkan oleh motor.

Lift dan eskalator merupakan sarana transportasi vertikal mekanis dalam sebuah bangunan. Pada bangunan publik diperlukan sejumlah unit lift yang ditentukan oleh kecepatan pergerakan manusia / barang yang diperlukan, dimensi lift, dan kecepatan mesin penggerak lift itu sendiri. Pada bangunan tinggi (high rise building) bahkan lift dibagi berdasarkan area lantai layanan tertentu (A. Fa'izin, 2006).

Berdasarkan jenisnya, lift dapat dibedakan menjadi lift barang (loading lift) dan lift penumpang (passenger lift). Lift barang atau lift di rumah sakit biasanya memiliki bukaan yang mampu terbuka secara menyeluruh, terkadang bahkan memiliki bukaan ke dua arah. Dimensi ruang lift yang meliputi panjang, lebar, dan tinggi merupakan faktor penentu daya tampung lift. Beberapa produsen lift menawarkan ukuran hose (ruang lift) yang berbeda-beda sesuai dengan daya tampung yang dibutuhkan. Untuk lift pada bangunan di atas 30 lantai, diperlukan lift yang memiliki kecepatan tinggi. Pada apartemen, kecepatan lift akan menentukan tingkat kenyamanan penghuni (tenant).

Untuk eskalator, persyaratan teknisnya lebih mirip seperti pada tangga statis yang terdiri dari unsur kemiringan (gradien), kecepatan pergerakan (flow capacity), dan lebar balustrade / handrail. Ketiga unsur tersebut menjadi tidak penting karena dapat diatasi dengan faktor kecepatan mesin penggeraknya. Pada beberapa kondisi tertentu, kombinasi antara lift dan eskalator sering kali diterapkan untuk kebutuhan fungsional dan estetika tertentu sebuah bangunan.

\section{Pelayanan Jasa}

Menurut Kotler (2002) definisi pelayanan adalah Tindakan dan kegiatan yang ditawarkan seseorang atau organisasi kepada pihak lain.. Dikatakan bahwa Pelayanan merupakan tindakan atau perilaku dari produsen untuk memenuhi kebutuhan dan keinginan dari pelanggan. Perilaku diatas dapat dilakukan pada saat, sebelum dan sesudah terjadinya transaksi. Bila konsumen puas makan akan terjadi pembelian.

Perusahaan yang bergerak di bidang jasa, kualitas pelayanan merupakan hal atau faktor yang harus diperhatikan Saat ini dalam memasarkan produk jasa terjadi secara langsung antara penjual dan pembeli. Kinerja organisasi dapat dlihat atau melalui Aplikasi perusahaan yang memuat informasi produk.

\section{Sistem Informasi}

Menurut definisi dari Nugraha, Sistem informasi adalah integral kegiatan dari manusia, fasilitas atau alat teknologi, media, prosedur dan pengendalian,untuk menata jaringan komunikasi, pengolahan atas transaksi - transaksi tertentu dan rutin, hal itu untuk membantu manajemen mengambil keputusan (Nugraha, 2010).

Sistem informasi merupakan sumber data utama yang dibutuhkan pengguna / pekerja di perusahaan. Sistem informasi yang berjalan dengan baik dan terpercaya dapat menunjang kegiatan operasional di perusahaan, semakin akurat sistem informasinya maka akan semakin 
produktif kegiatan operasional perusahaan dan sebaliknya, bila sistem informasi sebuah perusahaan tidak baik dan tidak akurat maka kegiatan operasional perusahaan akan mengalami banyak gangguan.

\section{Metode Sistem Basis Data}

Basis Data adalah Data yang terkumpul dan saling berhubungan diorganisasikan sesuai struktur tertentu. Untuk dapat informasi yang bermanfaat, maka diperlukan perangkat lunak untuk memanipulasi data, sehingga data bermanfaat.

Sistem basis data adalah sekumpulan dari file terhubung dengan program yang menyetujui dari pengguna dalam mengakses juga dapat merubah. Menurut definisi Sistem basis data atau Database Management Systems (DBMS) adalah sebuah software untuk membangun system basis data yang berbasis komputerisasi. DBMS dapat membantu dalam mengolah dan memelihara sejumlah besar data. Tujuannya dapat mengambil basis data secara efisien dan efektif.

Penggunaan basis data memudahkan setiap orang untuk melakukan aktifitasnya. Perkembangan managemen basis data dapat dikatakan begitu. Salah satu contoh aplikasi basis data, yaitu seperti dalam perbankan, penerbangan, perdagangan.

\section{Web Browser}

Pendapat dari Koeswandi (2004:175)

Web Browser adalah Program yang dapat berguna dalam menampilkan sebuah halaman dan mencari World Wide Web (WWW). Fungsi browser itu sendiri adalah dapat membuat format, menampilkan dan mengambil dokumen.. Beberapa Contoh web browser seperti adalah Mozila firefox dan Google Chrome. Web browser dapat dijalankan di berbagai platform baik UNIX dan Windows. World Wide Web (WWW), dapat berjalan melalui computer yang terhubung dengan internet.

Menurut Chaudhury (2002:190-191) Web browser dapat mengirim informasi mengenai halaman web dan nama domain untuk mendapatkan alamat lokasi fisik dan jalur ke lokasi halaman.

\section{Web Server}

Menurut Sibero (2013:11), web Server adalah perangkat keras dan lunak dalam sebuah computer. Perangkat kerasnya seperti computer PC, dengan perbedaan dalam kapasitas dan kapabilitas. Perangkat lunak diperlukan untuk web server bekerja dengan optimal. Menurut Anhar (2010:4), web server adalah sebuah aplikasi yang dapat difungsikan dalam menjawab permintaan alamat dari pengguna melalui web browser. Web Server akan mengirim informasi yang diinginkan melalui HTTP dapat dapat dilihat di layar monitor.

Menurut Ginting (2013:11), web server dapat dikatakan sebagai bagian inti dari suatu website. Dengan web server dapat mengetahui website yang ada di internet. Fungsi Web server mengontrol dan mengolah data web site untuk mengolah data pemakai dan kemudian dikembalikan ke pemakainya. Jenis web server antaralain IIS (Internet Information Services), apache dan Tomcat. Salah satu web server yang didukung format file server yang lengkap adlah Apache. Kelemahan dari IIS adalah tidak dapat membaca file server dengan format PHP.

\section{Analisis PIECES}

PIECES merupakan metode analisis dalam perancangan sistem informasi yang mencakup analisis terhadap kinerja, informasi, ekonomi, pengendalian, efisiensi dan pelayanan. Menurut Bustomi R. pada jurnalnya yang berjudul Perancangan Sistem Informasi Produksi (Studi Kasus Di PT. Selectrix Indonesia), kerangka PIECES digunakan untuk membantu mengidentifikasi, menganalisa, dan memecahkan masalah.

Metode PIECES adalah dapat digunakan untuk mendapatkan pokok pemasalahan lebih detail. Analisis sebuah sistem, antara lain dalam kinerja, ekonomi, efisiensi dan sebagainya. Dalam pengembangan sebuah sistem terlebih dahulu dilakukan analisis PIECES, sehingga dapat ditemukan masalah utama dan masalah turunan dari masalah utama (Nurjamiyah Arie, 2018).

Dalam mengembangan sistem dan menganalisi kebutuhan pengguna diperlukan metode ini. Disamping itu metode ini membantu organisasi membuat sistem yang terorganisir. seperti yang termuat dalam buku yang dikarang oleh Pressman, 2005. Kelebihan dari metode ini 
yaitu fleksibel dan kesesuaian dengan standar. Sehingga metode ini disebut dengan metode tangkas, karena mampu mendukung mengembangkan aplikasi dan dukungan teknik antara lain analisis sistem terstruktur, orientasi ekonomi, informasi teknik dan jasa pelayanan. Metode ini mempunyai beberapa kelemahan yaitu penggunaa terlalu banyak aspek dan waktu yang dibutuhkan cukup lama dan kebutuhan pemgembangan yang tepat.

\section{Pendekatan Terstruktur}

Pendekatan Terstruktur adalah suatu proses dalam aplikasi tahapan untuk menyelesaikan masalah. Pendekatan ini adalah kegiatan membantu penyelesaian masalah dalam kegiatan bisnis. Pendekatan ini dalam pengembangan sistem informasi penggunaannya berorientasi teknik dengan sistem yang jelas dan konsisten. Pendekatan ini memandang sistem secara logical dan sumber proses.

Menurut Hall \& Singleton dalam bukunya " Audit Teknologi Informasi dan Assurance ", pendekatan terstruktur merupakan metode yang teratur dalam merancang sistem, dengan urutan dari atas ke bawah. Awalnya dengan "gambaran umum" mengenai sistem yang diusulkan dan berlanjut pada yang makin rinci sebingga sistem dapat dimengerti. Dokumentasi dari Dalam pendekatan ini,adalah dengan menggunakan diagram aliran dara dan diagram struktur, urut dariatas ke bawah dalam proses bisnis.

Pendekatan terstruktur kelengkapannya adalah alat-alat (tools) dan teknik-teknik untuk mengembangan sistem sehingga mendapatkan sistem yang terstruktur dengan baik. (K. Kusrini, 2007).

\section{Flowchart}

Flowchart adalah gambaran urutan pemecahan masalah, yang ditandai dengan symbol, sesuai kegiatan tertentu. Dimulai dengan input dan diakhiri dengan output. (Wahyudi, 2010).

Tujuan dari flowchart adalah memudahkan penyelesaian masalah sehingga selanjutnya dapat dipelajari dan dievaluasi..

\section{METODE PENELITIAN}

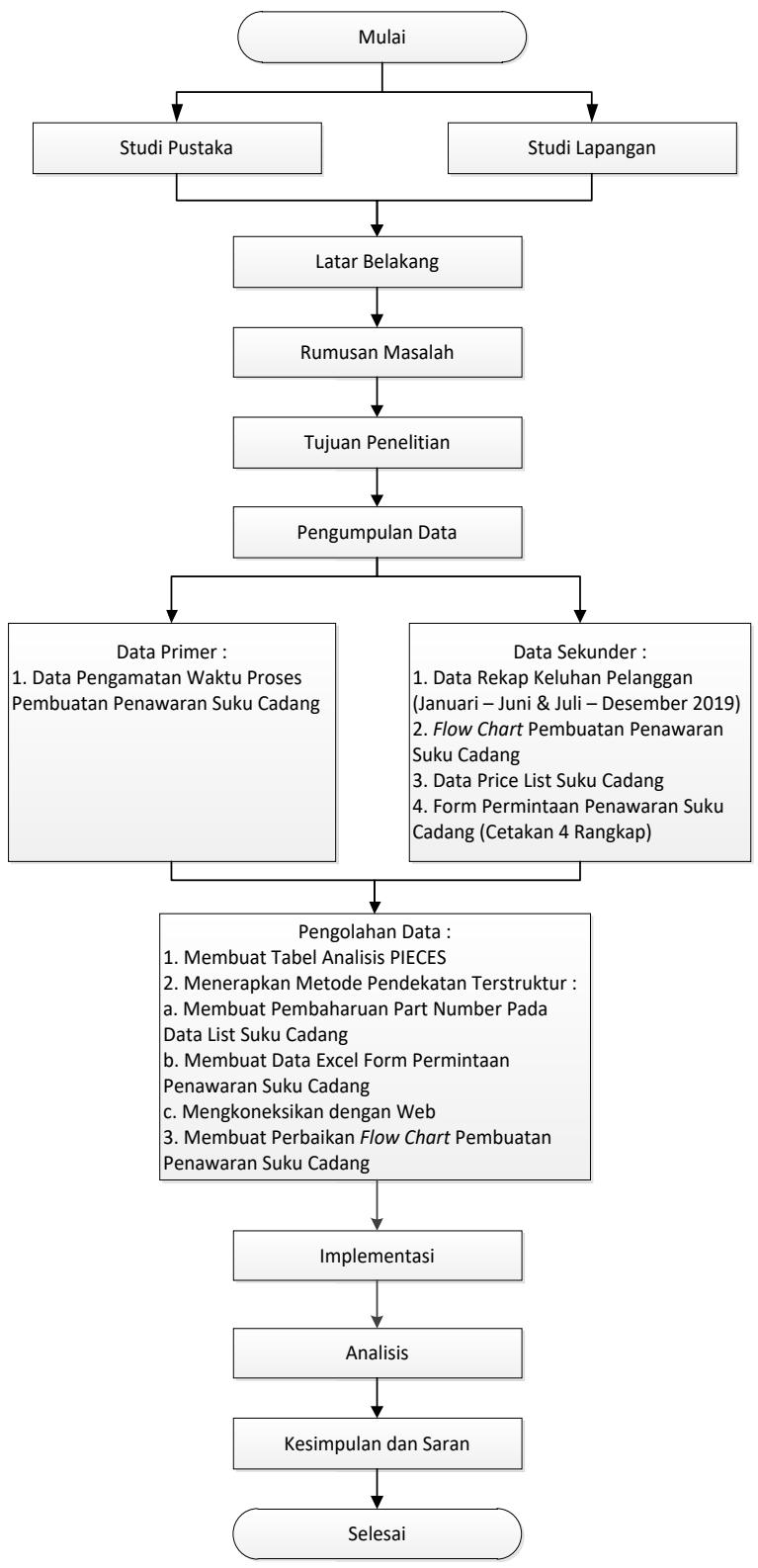

Gambar 1 Flowchart Metode Penelitian

\section{HASIL DAN PEMBAHASAN}

\section{Tabel Analisis PIECES}

Dalam perancangan sistem informasi pada penelitian ini menggunakan metode analisis PIECES untuk mendapatkan ilustrasi dari penggunaan dari aspek kinerja, informasi, ekonomi, pengendalian, efisiensi dan pelayanan. Analisis PIECES dibuatkan tabel untuk mengetahui kondisi sistem lama dan sistem yang baru. Dengan adanya tabel analisis PIECES dapat diketahui kondisi aktual sistem yang 
memiliki kendala dan sistem baru sesudah perbaikan dalam proses pembuatan penawaran suku cadang.

Dibawah ini tabel Analisis PIECES sistem informasi dalam proses pembuatan penawaran suku cadang sebagai berikut :

Tabel 3 Tabel Analisis PIECES

\begin{tabular}{|c|c|}
\hline Sistem Lama & Sistem Baru \\
\hline \multicolumn{2}{|c|}{ Analisis Kinerja (Performance Analysis) } \\
\hline $\begin{array}{l}\text { Semua aktivitas pencatatan dan pengecekan } \\
\text { Suku Cadang masih secara manual, berpotensi } \\
\text { menimbulkan kesalahan dalam memproses } \\
\text { data dengan sistem saat ini. }\end{array}$ & $\begin{array}{l}\text { Diharapkan pencatatan dan pengecekan Suku } \\
\text { Cadang bisa dilakukan lebih cepat dan tepat, } \\
\text { sehingga proses pembuatan penawaran tidak } \\
\text { terkendala. }\end{array}$ \\
\hline \multicolumn{2}{|c|}{ Analisis Informasi (Information Analysis) } \\
\hline $\begin{array}{l}\text { Kurang lengkapnya informasi yang dicantumkan } \\
\text { pada Form Permintaan Penawaran Suku Cadang } \\
\text { sehingga informasi yang dibutuhkan tidak } \\
\text { lengkap, tidak akurat dan sering terjadi } \\
\text { kesalahan penamaan suku cadang. } \\
\end{array}$ & $\begin{array}{l}\text { Diharapkan informasi yang dicantumkan pada } \\
\text { Form Permintaan Penawaran Suku Cadang } \\
\text { dapat diberikan dengan cepat dan jelas sesuai } \\
\text { kebutuhan karena informasi Suku Cadang } \\
\text { sudah terhubung dengan database dan server. }\end{array}$ \\
\hline \multicolumn{2}{|c|}{ Analisis Ekonomi (Economy Analysis) } \\
\hline $\begin{array}{l}\text { Adanya biaya pengeluaran untuk pembelian } \\
\text { kertas dan pencetakan form cetakan } 4 \text { rangkap. }\end{array}$ & $\begin{array}{l}\text { Biaya yang dikeluarkan hanya untuk pembelian } \\
\text { kertas, sudah tidak menggunakan form cetakan } \\
4 \text { rangkap. }\end{array}$ \\
\hline \multicolumn{2}{|c|}{ Analisis Pengendalian (Control Analysis) } \\
\hline $\begin{array}{l}\text { Sistem secara manual, akan sulit melakukan } \\
\text { kontrol karena pemrosesan data dilakukan } \\
\text { secara manual sehingga kemungkinan } \\
\text { terjadinya kesalahan sangat besar. }\end{array}$ & $\begin{array}{l}\text { Dapat lebih mudah mengontrol dan } \\
\text { mengoreksi apabila ada kendala yang dihadapi } \\
\text { Diharapkan hak akses data dapat diatur sesuai } \\
\text { status pengguna sehingga data tidak dapat } \\
\text { diakses oleh pengguna yang tidak } \\
\text { berkepentingan. }\end{array}$ \\
\hline \multicolumn{2}{|c|}{ Analisis Efisiensi (Efficiency Analysis) } \\
\hline $\begin{array}{l}\text { Dengan pencatatan dan pengecekan secara } \\
\text { manual, akan memakan waktu yang cukup lama } \\
\text { yang semestinya dapat diminimalisasi agar } \\
\text { proses selanjutnya tidak terlampau lama. }\end{array}$ & $\begin{array}{l}\text { Diharapkan dengan adanya sistem informasi in } \\
\text { maka pengguna dapat meningkatkan efisiensi } \\
\text { waktu dan memberikan pelayanan dengan } \\
\text { cepat untuk memenuhi permintaan pelanggan. }\end{array}$ \\
\hline \multicolumn{2}{|c|}{ Analisis Pelayanan (Service Analysis) } \\
\hline \begin{tabular}{|l|} 
Pelanggan harus menunggu lama untuk \\
mendapatkan Penawaran Suku Cadang karena \\
proses pembuatan sampai pengajuan \\
Penawaran Suku Cadang ke Pelanggan yang \\
memakan waktu 29 hari kerja.
\end{tabular} & $\begin{array}{l}\text { Pelayanan terhadap pelanggan diharapkan } \\
\text { dapat ditingkatkan dan lebih cepat karena data } \\
\text { yang dibutuhkan cepat diperoleh dan sudah } \\
\text { akurat. }\end{array}$ \\
\hline
\end{tabular}

\section{Pendekatan Terstruktur}

Perhitungan Pada permasalahan yang dihadapi dalam proses pembuatan penawaran suku cadang, proses-proses yang memiliki kendala harus diperbaiki terlebih dahulu dan kemudian disatukan kembali menjadi kesatuan proses pembuatan penawaran suku cadang dengan sistem informasi yang jelas dan akurat. Proses yang memiliki kendala yaitu proses yang memiliki keterlambatan dalam pelaksanaannya. Perbaikan pada proses yang memiliki waktu selisih antara waktu standar dan waktu aktual diharapkan dapat mengatasi permasalahan yang ada.

Proses yang harus diperbaiki antara lain proses pengiriman Form Permintaan Penawaran ke kantor pusat oleh Tim Operasional dan proses Pembuatan Penawaran Suku Cadang (Pemberian Harga) oleh Tim Marketing. Proses harus diperbaiki karena terkendala dalam pelaksanaannya. Waktu standar yang sudah ditentukan tidak bisa dipenuhi karena proses yang masih manual.

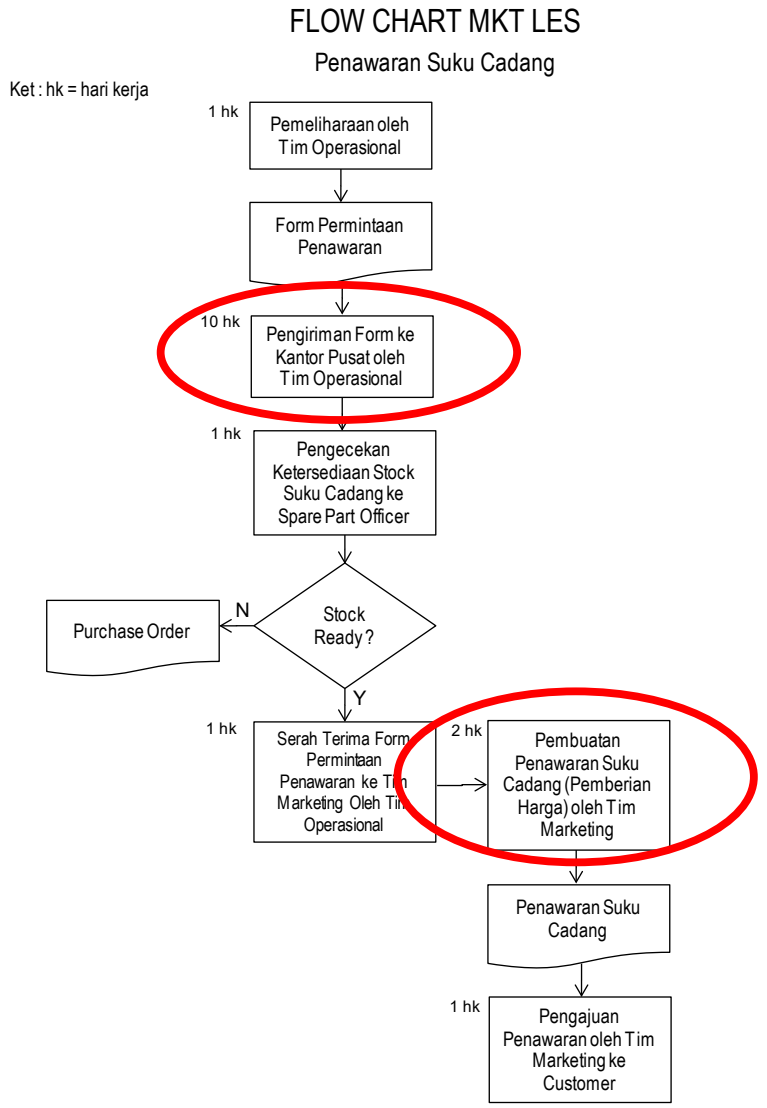

\section{Pembaharuan Part Number Paada Data List Suku Cadang}

Awal perbaikan dilakukan pada database untuk acuan pembuatan atau pengisian Form Permintaan Penawaran Suku Cadang. Data list suku cadang harus diperbaharui untuk menjadi acuan Tim Operasional saat ingin mengisi Form Permintaan Penawaran Suku Cadang. List yang sebelumnya dirapihkan, dihilangkan untuk data yang sudah tidak digunakan dan ditambahkan Part Number. Pembaharuan Part Number bertujuan untuk menjadi kode part atau nomor part dalam memilih suku cadang agar saat ingin mencantumkan suku cadang pada form, suku cadang dengan nama yang sama namun berbeda spesifikasi dapat dibedakan penulisannya. 


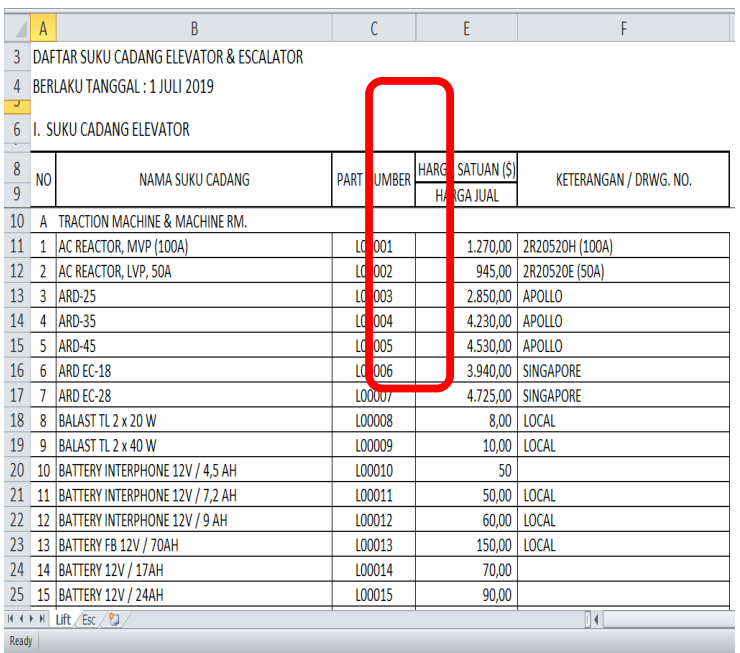

Gambar 2. Penambahan Part Number Pada List Suku Cadang

\section{Data Excel Form Permintaan Penawaran Suku Cadang}

Perbaikan selanjutnya yang dilakukan adalah membuat Form Permintaan Penawaran Suku Cadang dalam bentuk softcopy menggunakan format excel. Pembuatan form dalam bentuk excel ini bertujuan untuk memudahkan Tim Operasional dalam mengirim informasi perihal rekomendasi penggantian suku cadang ke kantor pusat. Pengiriman informasi secara online via email dapat mempersingkat waktu pengiriman Form Permintaan Penawaran Suku Cadang dibandingkan dengan pengiriman hardcopy secara manual. Format Excel mengikuti format Form Permintaan Penawaran Suku Cadang cetakan 4 rangkap secara keseluruhan sehingga subyek pada format form sebelumnya tetap berfungsi. Tim Marketing yang menerima Form Permintaan Penawaran juga bisa langsung memberikan harga untuk suku cadang yang akan ditawarkan. Dengan menggunakan rumus Vlookup pada Excel Form Permintaan Penawaran Suku Cadang, Tim Marketing dapat langsung memunculkan harga suku cadang berdasarkan part numbernya. Data excel Form Permintaan Penawaran Suku Cadang pada gambar 3.

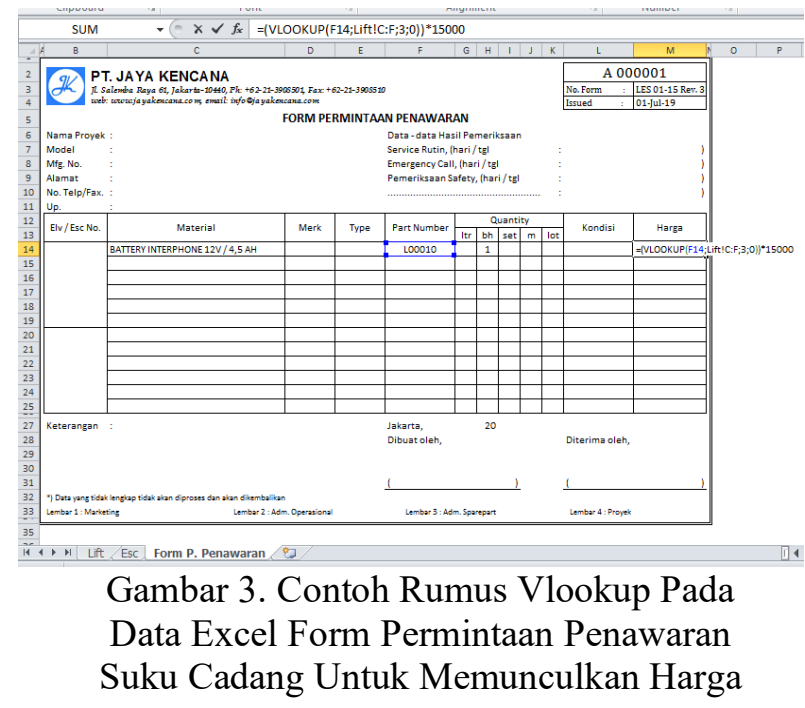

Rumus Vlookup berguna dalam menggambarkan data dalam tabel baik secara format tegak maupun vertical. Dengan referensi Part Number yang tercantum pada Form Permintaan Penawaran (kolom F4) dan mengacu pada Part Number di Data List Suku Cadang (Sheet Lift untuk suku cadang lift dan Sheet Esc untuk suku cadang eskalator) pada kolom Harga (berjarak 3 kolom dari kolom Part Number), maka rumus Vlookup dapat memunculkan harga dari suku cadang yang dimaksud. Harga suku cadang dengan satuan mata uang US Dollar dikonversi mengikuti nilai Rupiah yang berjalan (diasumsikan 1 US Dollar $=$ Rp. 15.000) dan dikalikan dengan rumus Vlookup.

Mengcopy rumus untuk seluruh suku cadang yang akan ditawarkan, mempermudah kerja Tim Marketing dalam pemberian harga. Sehingga Tim Marketing dapat langsung mengetahui harga dari suku cadang yang akan ditawarkan dan membuatkan penawarannya. Dengan tujuan waktu standar pembuatan penawaran dapat terpenuhi karena kendala yang dialami sebelumnya sudah diperbaiki yaitu Tim Marketing harus memastikan spesifikasi suku cadang terlebih dahulu agar tidak salah dalam memberikan harga. Kendala lain yang terjadi yaitu Tim Sparepart kesulitan dalam melakukan pengecekan ketersediaan stok suku cadang karena penulisan suku cadang yang kurang spesifik pada Form Permintaan Penawaran oleh Tim Operasional juga dapat teratasi. 


\section{Tahapan Koneksi Web}

Selain menggunakan email untuk pengiriman informasi, Excel Form Permintaan Penawaran juga dapat diakses menggunakan Web Server. Sebelumnya, perusahaan harus mendaftarkan jaringan internet terlebih dahulu agar Web Server dapat diakses melalui komputer maupun handphone (HP) untuk download ataupun upload data. Dengan mendaftar ke ISP (Internet Service Provider), fasilitas jaringan server atau internet dapat digunakan dengan dan atau tanpa LAN.

Dengan terhubungnya jaringan server atau internet, Web Server dapat diakses melalui komputer maupun handphone (HP) untuk download ataupun upload data Excel Form Permintaan Penawaran.

\section{Perbaikan Flowchart Pembuatan Penawaran Suku Cadang}

Proses-proses yang mengalami kendala

dilakukan perbaikannya yaitu dengan membuat pembaharuan Part Number pada List Suku Cadang dan membuat data Excel Form Permintaan Penawaran Suku Cadang. Sehingga alur proses Pembuatan Penawaran Suku Cadang perlu diperbaiki mengikuti proses-proses terbaru sesuai perbaikan yang dilakukan.

Alur proses Pembuatan Penawaran Suku Cadang yang sebelumnya belum terperinci perihal alur dokumen atau dokumen yang diarsipkan. Kemudian penanggung jawab dari masing-masing proses belum terperinci pembagiannya. Dengan adaya perbaikan Flow Chart Pembuatan Penawaran Suku Cadang diharapkan dapat memudahkan dalam mengimplementasikan perbaikan untuk proses pembuatan penawaran suku cadang dan mengatasi keluhan pelanggan yaitu lamanya proses pembuatan penawaran suku cadang.

Perbaikan Flow Chart Pembuatan Penawaran Suku Cadang seperti pada gambar dibawah ini :

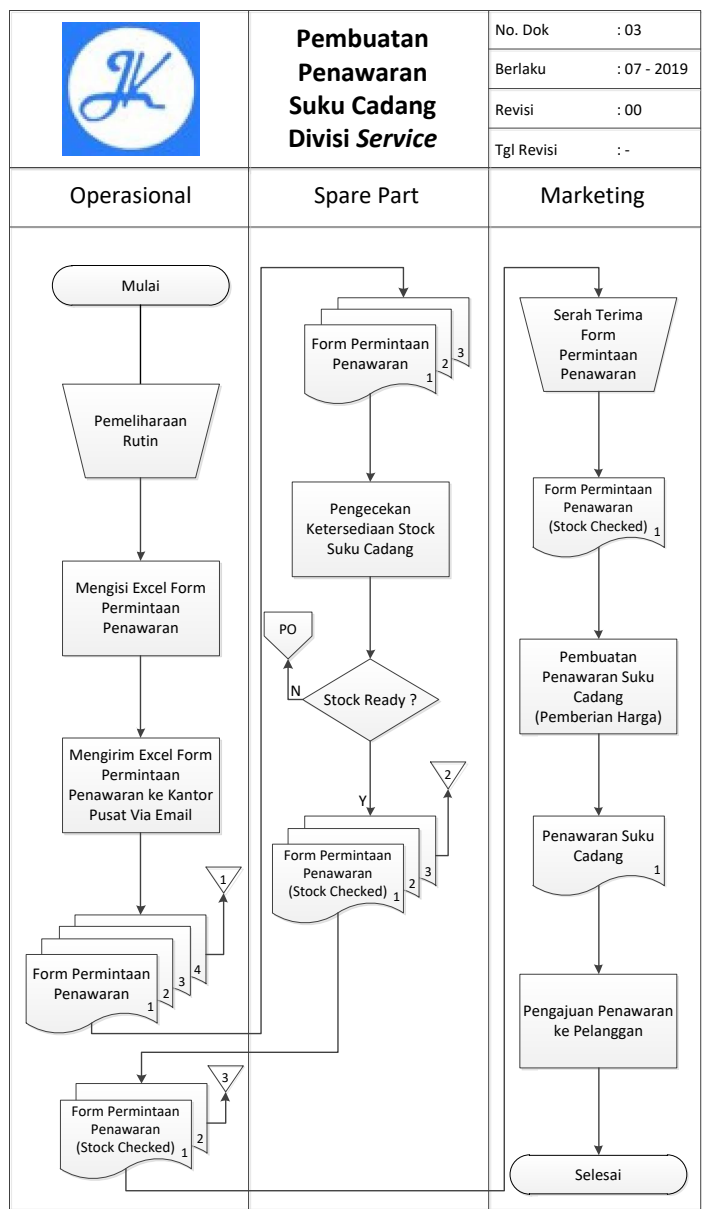

Gambar 4. Flowchart Perbaikan

Setelah adanya perbaikan Flow Chart Pembuatan Penawaran Suku Cadang, pelaksanaan proses pembuatan penawaran suku cadang menjadi lebih jelas dan terstruktur. Dalam pengaplikasiannya, perbaikan yang dilakukan mempermudah semua bagian pelaksana dari setiap prosesnya.

Proses-proses dalam pembuatan penawaran suku cadang setelah adanya perbaikan sistem informasi dimulai dari pemeliharaan unit lift dan eskalator oleh Tim Operasional, kemudian Tim Opersional di lapangan membuat rekomendasi penggantian suku cadang dengan mengisi Excel Form Permintaan Penawaran. Selanjutnya Excel Form Permintaan Penawaran dikirim ke kantor pusat melalui email. Tim Operasioal di kantor pusat mencetak Excel Form Permintaan Penawaran sebanyak 4 lembar, lembar ke-4 untuk diarsip oleh Tim Operasional di lapangan. Selanjutnya proses pengecekan ketersediaan stok suku 
cadang ke Sparepart Officer. Apabila stok suku cadang tidak tersedia, Tim Operasional akan mengajukan PO (Purchase Order) kepada Sparepart Officer. Apabila stok suku cadang tersedia, Form Permintaan Penawaran diserahkan kembali ke Tim Operasional dan lembar ke-3 untuk diarsip oleh Tim Sparepart. Kemudian Tim Operasional mengarsip lembar ke-2 Form Permintaan Penawaran untuk Tim Operasional di kantor pusat. Form Permintaan Penawaran lembar pertama diserahkan ke Tim Marketing untuk dibuatkan penawaran suku cadangnya (pemberian harga dengan acuan Excel Form Permintaan Penawaran) yaitu Tim Marketing menuangkannya dalam format penawaran suku cadang dan dilanjutkan dengan penandatanganan penawaran suku cadang oleh direksi. Setelah penawaran suku cadang ditandatangani, proses selanjutnya yaitu pengajuan penawaran suku cadang oleh Tim Marketing ke pelanggan dan proses pembuatan penawaran suku cadang selesai.

Setelah dilakukan perbaikan pada masing-masing proses, pembuatan penawaran suku cadang berjalan sesuai waktu standar yang sudah ditetapkan perusahaan. Kendala yang sudah diperbaiki diharapkan tidak terjadi lagi dengan penerapan alur proses kerja yang disiplin.

Tabel 4. Waktu Proses Pembuatan Penawaran Suku Cadang Setelah Perbaikan

\begin{tabular}{|c|c|c|c|}
\hline \multirow{2}{*}{ Proses } & \multicolumn{2}{|c|}{ Waktu Proses (hk) } & \multirow{2}{*}{$\begin{array}{c}\text { Selisih Waktu } \\
\text { Proses (hk) }\end{array}$} \\
\hline & Standar & Aktual & \\
\hline Pemeliharaan unit lift dan eskalator & 1 & 1 & 0 \\
\hline $\begin{array}{l}\text { Pembuatan \& Pengiriman Form Permintaan } \\
\text { Penawaran ke kantor pusat oleh Tim Operasional }\end{array}$ & 10 & 10 & 0 \\
\hline Pengecekan ketersediaan stok suku cadang & 1 & 1 & 0 \\
\hline $\begin{array}{l}\text { Form Permintaan Penawaran diserahkan ke Tim } \\
\text { Marketing }\end{array}$ & 1 & 1 & 0 \\
\hline Pembuatan penawaran suku cadang & 2 & 2 & $\mathbf{0}$ \\
\hline $\begin{array}{l}\text { Pengajuan penawaran suku cadang oleh Tim } \\
\text { Marketing ke pelanggan }\end{array}$ & 1 & 1 & 0 \\
\hline Total & 16 & 16 & $\mathbf{0}$ \\
\hline
\end{tabular}

\section{KESIMPULAN}

Berikut ini kesimpulan untuk menjawab tujuan dari penelitian :

1. Rancangan perbaikan sistem informasi pada proses pembuatan penawaran suku cadang yaitu pengiriman informasi rekomendasi penggantian suku cadang menggunakan Excel Form Permintaan Penawaran ke kantor pusat oleh Tim Operasional secara online via email dan dapat diakses melalui web server dan pembuatan penawaran suku cadang (pemberian harga) oleh Tim Marketing berdasarkan informasi Part Number pada Excel Form Permintaan Penawaran dan Data List Suku Cadang.

2. Hasil implementasi dari usulan rancangan perbaikan sistem informasi pada proses pembuatan penawaran suku cadang yaitu :

a. Pengiriman informasi rekomendasi penggantian suku cadang dalam bentuk Form Permintaan Penawaran ke kantor pusat oleh Tim Operasional sudah tidak mengalami keterlambatan lagi, yaitu pengiriman secara online via email dapat diakses melalui web server.

b. Pembuatan penawaran suku cadang (pemberian harga) oleh Tim Marketing sudah tepat waktu. Dengan berdasarkan informasi Part Number dan rumus pada Excel Form Permintaan Penawaran dan Data List Suku Cadang, Tim Marketing dapat langsung memunculkan harga suku cadang yang ingin dibuatkan penawaran menggunakan part numbernya.

c. Keluhan pelanggan terkait pembuatan penawaran suku cadang dapat teratasi dengan tidak adanya keluhan pelanggan lagi perihal lamanya proses pembuatan penawaran.

\section{DAFTAR PUSTAKA}

Al Fatta, H., "Analisis dan Perancangan Sistem Informasi untuk Keunggulan Bersaing Perusahaan dan Organisasi Modern",_Yogyakarta, Andi Offset, 2007

Arifin, Johar, "Microsoft Office Excel 2016 untuk Profesional", Jakarta, PT. Elex Media Komputindo, 2016.

Bustomi R., dkk, "Perancangan Sistem Informasi Produksi (Studi Kasus Di PT. Selectrix Indonesia)",_Teknik Industri, Universitas Trisakti.

Hall \& Singleton, "Audit Teknologi Informasi dan Assurance, Edisi 2", Jakarta, Salemba Empat, 2007.

Fa'izin A., "Ragam Bentuk, Bahan \& Variasi Tangga", Semarang, Griya Kreasi, 2006.

Jogiyanto, "Analisis \& Desain Sistem Informasi Pendekatan Terstruktur Teori dan Praktik 
Aplikasi Bisnis", Yogyakarta, Andi Offset, 2009. Jogiyanto," Sistem Informasi Berbasis Komputer : Konsep Dasar dan Komponen, Edisi Ketiga", Yogyakarta, BPFE, 2000.

Kusrini, K., "Tuntunan Praktis Membangun Sistem Informasi dengan Visual Basic dan Microsoft SQL Server", Yogyakarta, Andi Offset, 2007.

Marlinda, Linda, "Sistem Basis Data", Yogyakarta, Andi, 2004.

Mubarrok, Adib, "Rumus EXCEL", Jakarta, PT. Elex Media Komputindo, 2015.
Nugraha, D., "Pengelolaan Sistem", Jakarta, Gramedia, 2010.

Nurjamiyah, Arie. Analisis system informasi pengolahan data nilai mahasiswa menggunakan PIECES pada STTH Medan. Prodi Sistem Informasi, Universitas Harapan Medan.

Ristono, Agus, "Pemodelan Sistem", Jakarta, Graha Ilmu, 2010.

Tjiptono, Fandy, "Manajemen Jasa", Edisi Kedua, Jakarta, Andy Offset, 2000. Wahyudi, B. Peracangan Sistem. Bandung. Informatika.2010. 